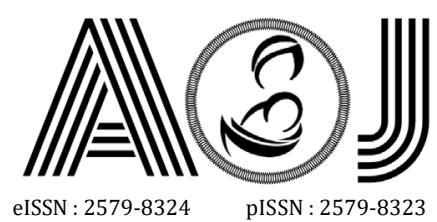

eISSN : 2579-8324
pISSN : 2579-8323

\title{
RESEARCH
}

\section{Diagnostic Value of Cyclooxygenase-2 Serum Levels in Predicting Preterm Labor}

Wiwin Suhandri ${ }^{1}$, Dovy Djanas ${ }^{2}$

Affiliations: 1. Resident of Obstetrics and Gynecology, Faculty of Medicine, Andalas University, Dr. M. Djamil Central General Hospital Padang; 2. Sub Division of Maternal Fetal Medicine, Obstetrics and Gynecology Department, Faculty of Medicine, Andalas University, Dr. M. Djamil Central General Hospital Padang

Correspondence: Wiwin Suhandri,email:wiwin.suhandri@gmail.com, Hp:081276961991

\section{Abstract}

Objective: To determine the value of serum cyclooxygenase 2 in predicting preterm labor

Method: Examination of serum COX-2 levels by ELISA method in pregnant women with 28 weeks to 36 weeks of pregnancy compared with pregnant women with $\geq 37$ weeks of gestation at the time of first stage of active phase

Results: It is known that the average COX-2 level in preterm labor is $21.88 \pm 18.22$ higher than in term labor which is $4.88 \pm 2.35 \mathrm{ng} / \mathrm{ml}$, the statistical test results obtained $p=<0.001$ serum Cyclooxygenase 2 at preterm deliveries and term deliveries. The value of serum cyclooxygenase 2 levels in predicting preterm labor is at a cut point of 7.0.0 $\mathrm{ng} / \mathrm{ml}$ with a sensitivity of $86.1 \%$ and a specificity of $86.1 \%$

Conclusion: There were significant differences in serum cyclooxygenase 2 levels in preterm labor and term delivery

Keywords: cyclooxygenase 2, memprediksi persalinan preterm, persalinan preterm.

\section{INTRODUCTION}

Preterm labor is a cause of perinatal morbidity and mortality worldwide. Preterm labor causes 70\% perinatal and neonatal mortality, and long-term morbidity, which includes mental retardation, cerebral palsy, developmental disorders, seizure disorders, blindness, hearing loss, and non neurological disorders, such as chronic lung disease and neuropathy. WHO defines preterm labor as labor at less than 37 weeks' gestation or less than 259 days, counting from the first day of the last menstrual cycle, or with a birth weight less than $2500 \mathrm{~g}^{1,2}$.

Seventy percent of the incidence of preterm labor with a gestational age of less than 30 weeks is related to intrauterine infection, compared with gestational age of more than 30 weeks (30-40\%). In preterm labor, labor is triggered before term. Triggers for these pathological conditions include intra-uterine infection, uterine over distention, uteroplacental ischemia, cervical abnormalities and other things that cannot be explained. Of the several triggers above intra uterine infection causes $40 \%$ of preterm labor $^{3}$. The mechanism of preterm labor induced by infection is basically an inflammatory reaction that is influenced by maternal and fetal factors. Bacterial invasion will produce bacterial products 


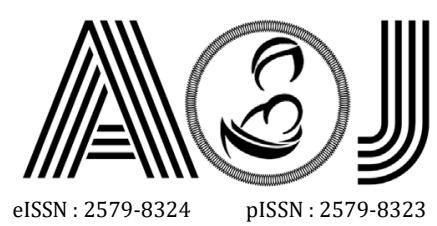

Ruang Redaksi Andalas Obstetrics and Gynecology Journal, Lantai 3 PPDS Obstetri dan Ginekologi Universitas Andalas, RSUP DR. M. Djamil Padang, Jl. Perintis Kemerdekaan Padang, Sumatera Barat 25127

in the form of phospholipase A2 (PLA2), endotoxin and collagenase. The product will stimulate a cytokine cascade characterized by the formation of interleukin-1 (IL-1), tumor necrosing factor (TNF), interleukin-6 (IL-6), interleukin-8 (IL-8) by macrophages and inflammatory cells decidua activated. ${ }^{3}$

PLA2 will induce glycerophospholipids from cell membranes and then turn into arachidonic acid and subsequently produce cytokine cascades to produce prostaglandin E2 (PGE2) through the COX - 2 pathway. Actually arachidonic acid produced by that process. It will be partly converted through the lipoxygenase pathway into leukotrienes (LT) and 5hydroxyecoisatetraenoiic acid (5-HETE) and then stimulates uterine contractions ${ }^{4}$.

\section{METHOD}

The study was an observational analytic study with a cross sectional comparative study approach. This study was conducted on all patients who experienced preterm labor at the first active phase and gestational age between 28 (+ 0 days) week and 36 (+ 6 days) weeks which were assessed based on the last menstrual period (LMP) and or patients who had already on USG from the 1st trimester of pregnancy during 2019. It carried out in the Obstetrics and Gynecology Section / SMF of Network Hospital, Community Health Center, General Central Hospital of Dr. M. Djamil Padang and at the Biomedical Laboratory, Faculty of Medicine, Univesitas Andalas, Padang. The controls were women who had term deliveries ( $\geq 37$ weeks) during the first active phase who were treated in the Obstetrics and Gynecology Section of the Network Hospital, the Network Health Center and the Central General Hospital of Dr. M. Djamil Padang. Sampling in research is by Consecutive Sampling. Samples were examined for COX-2 serum levels by the ELISA method.

\section{RESULT}

The research subjects consisted of 72 respondents, of which 36 respondents with preterm labor and 36 respondents with term labor at the active phase

\section{Data Normality}

Data normality test results can be seen in Table 1. below:

Table 1. Data Normality Test

\begin{tabular}{cccc}
\hline COX-2 & $\mathbf{n}$ & Mean $\mathbf{S}$ SD & p value \\
\hline Preterm labor & 36 & $21,88 \pm 18,22$ & 0,057 \\
Term Labor & 36 & $4,88 \pm 2,35$ & 0,069 \\
\hline
\end{tabular}




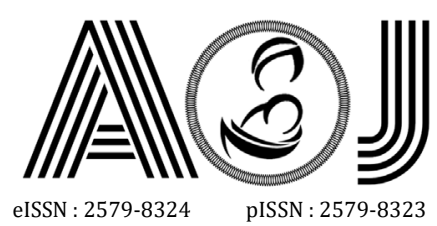

Ruang Redaksi Andalas Obstetrics and Gynecology Journal, Lantai 3 PPDS Obstetri dan Ginekologi Universitas Andalas, RSUP DR. M. Djamil Padang, Jl. Perintis Kemerdekaan Padang, Sumatera Barat 25127

Based on table 1 it is known that the results of the normality test of COX-2 levels of respondents in preterm and term delivery were normally distributed $(p>0.05)$.

\section{Characteristics of Respondents}

Table 2. Characteristics of Respondents by Age

\begin{tabular}{cccc}
\hline Variabel & Preterm (Mean \pm SD) & Term (Mean \pm SD) & $p$-value \\
\hline Age (years) & $29.03 \pm 4.76$ & $30.03 \pm 4.60$ & 0.368 \\
Parity & $1.64 \pm 1.39$ & $1.47 \pm 1.25$ & 0.596 \\
Body mass index $\left(\mathrm{kg} / \mathrm{m}^{2}\right)$ & $21.52 \pm 1.34$ & $22.09 \pm 1.97$ & 0.154 \\
Leukocytes & $12.715,83 \pm 1.132,13$ & $11.000,00 \pm 1.293,94$ & 0.001 \\
\hline
\end{tabular}

Based on Table 2. there were no differences in the mean age, parity and body mass index of respondents in preterm and term delivery $(p>0.05)$. However, there were differences in leukocyte levels in preterm and term labor $(p<0.05)$.

\section{Differences in Serum Cyclooxygenase $\mathbf{2}$ Levels in Preterm Labor and Aterm Labor}

Table 3. Differences in Levels of Serum Cyclooxygenase 2 in Preterm and Term Labor

\begin{tabular}{cccc}
\hline COX-2 & $\mathbf{n}$ & Mean \pm SD & p-value \\
\hline Preterm Labor $(\mathrm{ng} / \mathrm{ml})$ & 36 & $21.88 \pm 18.22$ & $<0.001$ \\
Term Labor $(\mathrm{ng} / \mathrm{ml})$ & 36 & $4.88 \pm 2.35$ & \\
\hline
\end{tabular}

Based on Table 3 the mean of COX-2 levels in preterm labor are higher then term labor. The statistical test results obtained $p$ value $<0.001$, it can be concluded that there are significant differences in serum cyclooxygenase 2 levels in preterm labor and term labor.

\section{Diagnostic Value of Cyclooxygenase 2 Serum Levels in Predicting Preterm Labor}

The diagnostic value of serum cyclooxygenase 2 levels in predicting preterm labor can be done through Receiver Operating Characteristic (ROC) analysis, shown in Figure 1

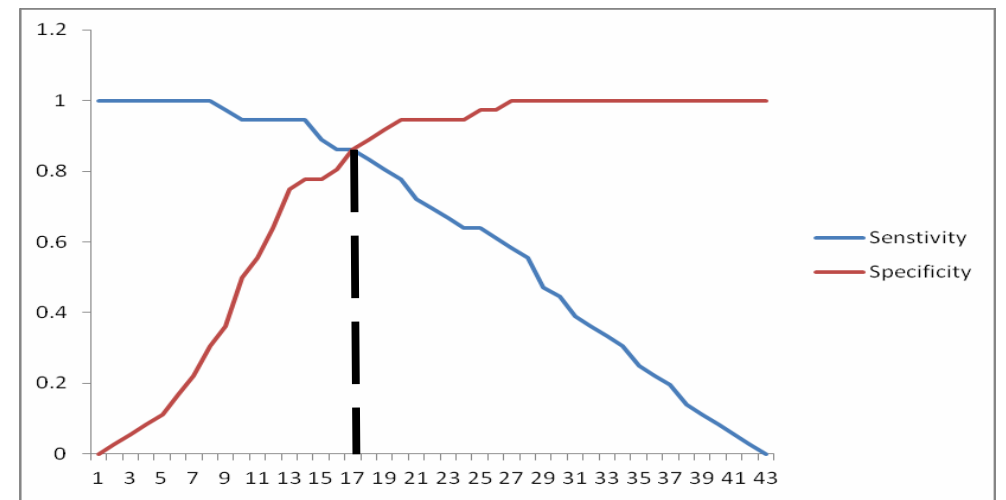

Figure 1. Sensitivity and Specificity Based on Cut-Off Points According to ROC (Receiver Operating Characteristic) Analysis 


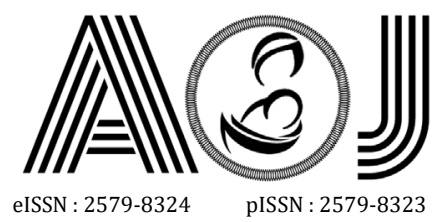

eISSN : 2579-8324

Ruang Redaksi Andalas Obstetrics and Gynecology Journal, Lantai 3 PPDS Obstetri dan Ginekologi Universitas Andalas, RSUP DR. M. Djamil Padang, Jl. Perintis Kemerdekaan Padang, Sumatera Barat 25127

From Figure 1. it is known that the optimal cut point at the intersection of the sensitivity and specificity line is point 17. The diagnostic value of serum cyclooxygenase 2 levels in predicting preterm labor at cut-off point 17 is $7.039 \mathrm{ng} / \mathrm{ml}$ whose sensitivity value is $86.1 \%$ and the specificity is $86.1 \%$. The accuracy of serum cyclooxygenase 2 levels in predicting preterm labor can be seen in the following figure 2 .

\section{ROC Curve}

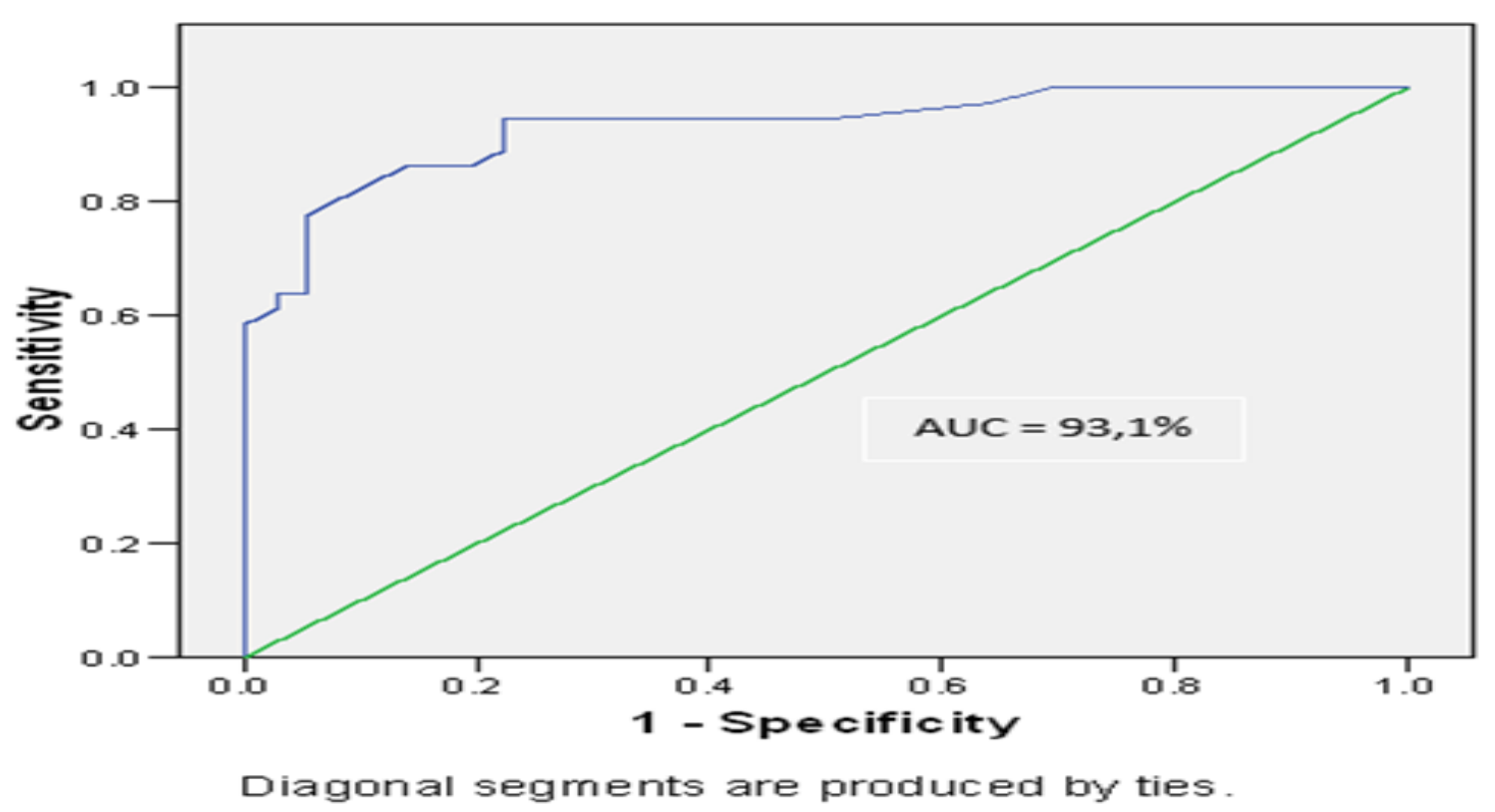

Figure 2. Accuracy of Cyclooxygenase 2 Serum Levels in Predicting Preterm Labor

Based on Figure 2, the value of area under the curve (AUC) in the ROC analysis was $93.1 \%$, it can be concluded that the accuracy of cyclooxygenase 2 serum levels in predicting preterm labor is very good accuracy category.

\section{DISCUSSION}

\section{Differences in Serum Cyclooxygenase 2 Levels in Preterm Labor and Term Labor}

The statistical test results obtained $p$ value $<0.001$, it can be concluded that there are significant differences in serum cyclooxygenase 2 levels in preterm labor and term labor. These results are in line with previous studies conducted by Loudon (2003) where there were differences in COX-2 levels in preterm and term labor. The level of COX-2 in preterm labor was $16.13 \pm 4.71 \mathrm{ng} / \mathrm{ml}$ higher than in term labor $10.11 \pm 5.69 \mathrm{ng} / \mathrm{ml}$. Stating the average COX-2 in preterm labor was $88.75 \%$ compared to $46 \%$ in normal labor.

Another study conducted by Djanas (2018) found that COX-2 levels were higher in preterm labor which was $11.02 \pm 3.33 \mathrm{ng} / \mathrm{ml}$ compared to term delivery at $8.77 \pm 1.36 \mathrm{ng}$ / 


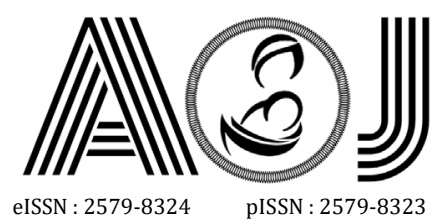

eISSN : 2579-8324
pISSN : 2579-8323

Ruang Redaksi Andalas Obstetrics and Gynecology Journal, Lantai 3 PPDS Obstetri dan Ginekologi Universitas Andalas, RSUP DR. M. Djamil Padang, Jl. Perintis Kemerdekaan Padang, Sumatera Barat 25127

$\mathrm{ml}$, the statistical test results obtained $p=0.012(p$ value $<0.05)$ then there are differences in COX-2 levels between preterm labor and term delivery.

Based on the theory there is a relationship between preterm labor and subclinical inflammatory response in maternal or fetal tissue. Seventy percent of the incidence of preterm labor with a gestational age of less than 30 weeks is associated with intrauterine infection. Infection is an important disease mechanism in preterm labor.

This infection process is followed by an inflammatory response which includes the secretion of cytokines / chemokines by the body and infiltration of immune cells into the reproductive tissues and the fetus / mother. Pro-inflammatory cytokines stimulate the production of matrix metalloproteinases (MMP) -2, -8, -9, COX-2, collagenases and prostaglandins which cause cervical softening and rupture of the membranes. TNF- $\alpha$ and IL- $\beta$ increase contractility whereas COX-2, PGE-2, IL-6 regulates OT receptors in myometrial cells that play a role in myometrial contractility ${ }^{5}$.

Infection triggers proinflammatory cytokine stimulation, namely TNF-a, which plays a role in the activation of Nuclear Factor Kappa Beta (NF-kB) and COX-2. The presence of proinflammatory cytokines has an effect on cell membrane phospholipids altered by phospholipase $\mathrm{A} 2$ and will increase arachidonic acid and form prostaglandins by activation of high COX-2. Increased COX-2 also affects the functional withdrawal of progesterone through the interaction of progesterone receptors thereby increasing prostaglandin levels ${ }^{6}$. Increased prostaglandin levels cause activation of the enzyme collagenase, blood vessel dilatation and uterine contractions ${ }^{7}$. Activation of amnion cytokines, decidua and chorion will increase apoptosis, through the process of amniotic membrane damage, reduction in cell density and degradation of the extracellular matrix which triggers thinning of the membranes causing rupture of membranes ${ }^{8}$. This explains that the combination of cervical dilatation, uterine contractions and rupture of membranes can cause premature labor ${ }^{9}$.

Researcher's analysis found that differences in COX-2 levels in preterm labor were higher than in term labor due to inflammation that occurs in preterm labor, activating proinflammatory cytokines that can stimulate myometrial contraction through increased synthesis of TNF-a which increases COX-2 levels so that in the end, it will increase prostaglandin levels, prostaglandins will further increase intracellular calcium uptake so that calcium levels that can be used by the myometrium increase and then will cause contractions. Conditions of contraction triggers preterm labor.

\section{Diagnostic Value of Cyclooxygenase 2 Serum Levels in Predicting Preterm Labor}

Based on the result, it can be concluded that the accuracy of cyclooxygenase 2 serum levels in predicting preterm labor is very good accuracy category. The research stated that COX-2 may be a predictor in determining the occurrence of preterm labor, an increase of COX-2 in 


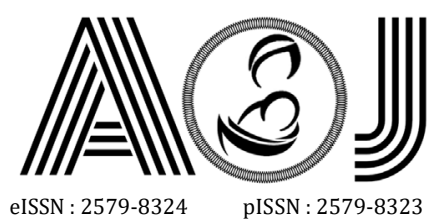

eISSN : 2579-8324
pISSN : 2579-8323

Ruang Redaksi Andalas Obstetrics and Gynecology Journal, Lantai 3 PPDS Obstetri dan Ginekologi Universitas Andalas, RSUP DR. M. Djamil Padang, Jl. Perintis Kemerdekaan Padang, Sumatera Barat 25127

$86 \%$ of labor may determine the risk of preterm labor ${ }^{10}$. Meta-analysis stated that the discovery of the effect of COX to the occurrence of preterm labor, it is necessary to treat with COX-2 inhibitors for the prevention and treatment of preterm labor ${ }^{11}$.

Progesterone and COX-2 markers as a determinant of success in the prevention of preterm labor. They form a computer simulation with linear equations to predict the risk of preterm labor, which is expected that application can prevent preterm labor and prevent high-cost treatment ${ }^{12}$.

Preterm labor begins with high levels of prostaglandins in the amniotic fluid. Prostaglandins (PG) are able to soften the cervix by increasing proteoglycans and changing the biophysical properties of collagen ${ }^{7,8}$. Prostaglandins are a form of prostanoids. Prostanoid production at the site of injury is a major component of the inflammatory reaction. Prostanoids are formed by arachidonic acid which is from phospholipid membranes, with the help of phospholipase-A2, Cyclooxygenase-2 (COX-2) can convert arachidonic acid into prostaglandin $\mathrm{H}$, then convert it to specific prostanoid species, for example prostaglandin $\mathrm{E} 2^{6}$. COX2 is triggered by IL-1 and TNF-a, both of themwere formed a few hours after the onset of inflammation. Increasing of endometrial COX-2 and prostaglandins, and uterine contractions causing ischemia and pain.

Excessive secretion from inflammatory cytokines as occurs in amniotic infections causes adverse effects on intra-uterine tissue such as abortion and preterm labor. The absence of proinflammatory cytokines, such as COX-2, is expected to play an important role in preterm labor and term labor by changing the status of the uterus from rest to an active state ${ }^{6,7}$.

Based on the analysis of researchers in the case of preterm labor, COX-2 plays a role in stimulating uterine activity and cervical maturation process by producing prostaglandins, cortisol and degrading extracellular matrix from the amniotic membrane. In preterm labor, COX-2 levels increased. Therefore, It is necessary to use COX-2 levels as a predictor in predicting preterm labor by utilizing the diagnostic value found by researchers.

\section{CONCLUSION}

There are significant differences in serum levels of cyclooxygenase 2 in preterm labor and term labor. The diagnostic value of Cyclooxygenase 2 serum levels in predicting preterm labor is at a cutoff point of $7.039 \mathrm{ng} / \mathrm{ml}$ with sensitivity value is $86.1 \%$, specificity value is $86.1 \%$, and accuracy is 93.1 


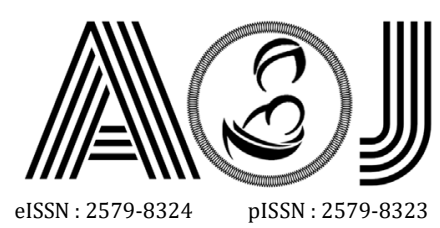

Ruang Redaksi Andalas Obstetrics and Gynecology Journal, Lantai 3 PPDS Obstetri dan Ginekologi Universitas Andalas, RSUP DR. M. Djamil Padang, Jl. Perintis Kemerdekaan Padang, Sumatera Barat 25127

Website:

http://jurnalobgin.fk.unand.ac.id/index.php/JOE

\section{REFERENCES}

1. Buhimschi CS, NormanJE, Creasy RK, Resnik R, lams JD, Lockwood CJ, Moore TR, et al. In Creasy \& Resnik's Maternal-Fetal Medicine Principles and Practice. Elsevier. 2014: 599-623.

2. WHO. Preterm Birth. Fact Sheet. 2016.

3. Prawiroharjo, Sarwono. Ilmu Kebidanan. 4th ed. Jakarta: PT Bina Pustaka Sarwono Prawiroharjo; 2010: 667-676

4. Abadi A. Persalinan preterm, Ilmu Kedokteran Fetomaternal. Surabaya: Himpunan Kedokteran Fetomaternal POGI; 2004: 364-380.

5. Shenavai S, Preissing S, Hoffmann B, Dilly M, Pfarrer C, Ozalp G, et al., Investigations into the mechanisms controlling parturition in cattle: Soc Reprod Fertil. 2010; 144: 279-92.

6. Condon JC, Hardy DB, KovaricK, Mendelson CR.. Up-Regulation of the Progesterone Receptor (PR)-C Isoform in Laboring Myometrium by Activation of Nuclear Factor-kB May Contribute to the Onset of Labor through Inhibition of PR Function. Mol Endocrinol.2006; 20 (4): 764-75.

7. Jacques AL. Two different regimen of preinduction ripening of the uterine servix with prostaglandin E2: randomized clinical study. Eur J Obstet Gynecol Reprod Biol.1993; 50 (3): 163-8.

8. Sagol S. Role of apoptosis, bcl-2 and bax protein expression in premature rupture of fetal membrane. J Reprod Med.2002; 47 (10): 809-15.

9. Palliser HK, Hirst J, Ooi GT, Rice G, Dellios N, et al. Prostaglandin E dan F Receptor Expression and Myometrial Sensitivity at Labor Onset in the Sheep. Biol Reprod.2004; 72: 937-43.

10. Mogami H, Kishore AH, Shi H, Keller PW, Akgul Y, Word RA. Fetal Fibronectin Signaling Induces Matrix Metalloproteases and Cyclooxygenase-2 (COX-2) in Amnion Cells and Preterm Birth in Mice. J Biol Chem.2013; 288: 1953-66.

11. Reinebrant HE, Pileggi-Castro C, Romero CLT, Dos Santos RAN, Kumar S, Souza J, Flenady V. Cyclo-oxygenase (COX) inhibitors for treating preterm labour. Cochrane Systematic Review. 2015; 6

12. Equils O, Nambiar P, HobelCJ, Smith R, Simmons CF, Vali S. A Computer Simulation of Progesterone and Cox2 Inhibitor Treatment for Preterm Labor. PLoS ONE.2010; 5 (1): 8502. 